\title{
УПРАВЛІННЯ ТУРИСТИЧНОЮ ДІЯЛЬНІСТЮ В УКРАЇНІ: ТЕОРЕТИЧНИЙ АСПЕКТ
}

У статті розкрито теоретичні аспекти управління туристичною діяльністю в Україні. Звернено увагу на регламентування, координацію, стимулювання, інформаційне забезпечення, просування національного туристичного продукту. Висвітлено моделі управління туристичною діяльністю. Зокрема, периа модель зорієнтована на розв'язування туристичних проблем через ринкові механізми. У другій моделі передбачено наявність міністерства, яке контролюе туристичну діяльність; у третій - при міністерстві існуе підрозділ, який займається туристичною діяльністю. Акцентовано на основних засобах регулювання туристичної діяльності, як-от: стандартизація, сертифікація та ліцензування в туристичній сфері. Сертифікація - ц̧е діяльність, щ̧о забезпечуе відповідність продукцї функціональному призначенню. Це сукупність дій $i$ процедур, проведених з метою підтвердження того, що продукт чи послуга відповідае певним стандартам, це документальне засвідчення відповідності продукц̧ї чи інших об'єктів, процесів виробництва, експлуатації надання послуг положенням стандартів чи умовам договорів. Аіцензування визначається як надання певного дозволу на туристичну діяльність. Це процес видання, переоформлення та анулювання ліцеензій, ведення ліцензійних справ та реєстрів, контролю за дотриманням ліцензійних умов, видання розпоряджень про усунення порущень ліцензійних умов. Стандартизація розкривається як установлення норм, правил з метою забезпечення безпеки туристичних послуг. Вказано, щзо метою стандартизації у сфері туризму є забезпечення якості та ефективності туристичного екскурсійного обслуговування $і$ захист інтересів споживачів туристичних послуг.

Незважаючи на складні політичні, соціально-економічні умови, карантинні обмеження останніх років вітчизняний туризм розвивається як пріоритетна галузь господарського комплексу Украӥни.

Ключові слова: туристична діяльність, украйна, управління, моделі управління туристичною діяльністю, засоби управління туристичною діяльністю.

Постановка проблеми. На сучасному етапі розвитку суспільства туризм став потужним соціально-економічним та політичним явищем, яке істотно впливає на світовий устрій і політику окремих держав і України зокрема. Сучасна туристична галузь стрімко та динамічно розвивається, випереджуючи за темпами зростання доходів нафтогазовидобувну промисловість та автомобілебудування. Результати досліджень, проведених Всесвітньою туристичною організацією, передбачають зростання туристичного руху в усіх країнах світу, що забезпечують збільшення витрат на трильйони доларів США.

Феноменальний успіх туризму зумовлений його спрямованістю на задоволення постійних потреб людини у відпочинку, пізнанні навколишнього світу. Це можливо завдяки успішному розвитку України та інших країн світу, підвищенню рівня добробуту населення, удосконалення туристичних послуг та управління туристичною діяльністю.

У сфері туризму інтегруються інтереси економіки та культури, безпеки та міжнародних відносин, екології й зайнятості населення, готельного, ресторанного бізнесу і транспортних організацій [2].

*(C) Шоробура I. M.

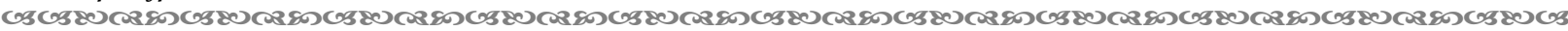
202 
Організація Об’єднаних Націй, Всесвітня туристична організація і ЮНЕСКО XXI століття визнали століттям туризму, який спільно із телекомунікаційними та інформаційними технологіями сприятиме економічному зростанні України та світу.

За роки незалежності в нашій державі туризм сформувався як самостійний реальний сектор 3 високою економічною ефективністю, що сприяе збільшенню валового національного доходу і високої зайнятості населення в туристичному бізнесі та супутніх галузях. Важливу роль у цьому контексті відіграє управління туристичною діяльністю в Україні

Аналіз досліджень. Визначення поняття туризму, туристичної діяльності, управління нею, їхніх структурних компонентів важливо для прогнозування закономірностей державного управління цією системою, іï вплив на економіку та регіональний розвиток держави.

На думку вчених, зокрема А. Александрової, Л. Аук'янової, В. Цибух, туризм є соціально-економічною сферою діяльності та самостійною складовою рекреації. Це вид рухдивого активного відпочинку, який здійснюється в основному в період відпустки.

Питаннями туризму займахись такі зарубіжні вчені: Shaffer, Clawson, Knetsch, Cribier, Leimgruber, Held, Stoddart, Ruppert, Maier, Heller та ін., які виділяють один найбільш поширений аспект відпочинку - туризм. While Gruntal та Roser визнавали туризм як один із головних чинників рекреаційної діяльності, як частину економічної та транспортної географії [3].

Вивченню проблеми туристичної діяльності присвячено ряд публікацій вітчизняних і зарубіжних науковців: М. Мальської, М. Рутинського О. Дюбіцевої, М. Жукової, В. Киф'яка та ін. Найбільш аргументованими є дослідження М. Рутинського, де вдало обгрунтовано доцільність вживання терміна, вказано на міжгалузевий характер індустрії подорожей. Проблемами управління туристичною діяльністю займалися науковці В. Киф'як, В. Кіптенко, Н. Кудла, О. Кузьмін та ін. Вони висвітлюють правове регулювання туристичної діяльності, проблеми стандартизації, діцензування та ін.

Серед учених ведуться гострі дискусії та відсутня єдність стосовно цієї проблеми. Так, одна група вчених обгрунтовуе доцільність використання терміна «туристична галузь», інші - заперечують можливість вживання такого терміна і пропонують натомість - «туристичний комплекс». Очевидно, що відсутність єдиної термінології у цій сфері негативно впливає і на інші дослідження туризму - так важко визначити роль і місце туризму в економіці України, якщо відсутне саме поняття «туристичного комплексу» [8].

Мета статті - розкрити теоретичні аспекти державного управління туристичною діяльністю в Україні, показати моделі та засоби управління, зокрема особливості стандартизації, сертифікації та діцензування.

Виклад основного матеріалу. Державне регулювання туристичної діяльності здійснюється на основі іiі регламентування законодавчими актами у туристичній галузі, зокрема законом України «Про туризм» та іншими.

Регулювання туристичної діяльності у контексті держави здійснюється також шляхом стимулювання міжнародних обмінів, створення умов для розвитку внутрішнього туризму. Держава має гарантувати безпеку туристичної діядьності, інформаційне забезпечення, випуск рекламно-інформаційних матеріалів тощо. До функцій держави належить просування національного туристичного продукту на міжнародному ринку. Це презентації, участі в різноманітних організаційних заходах, реклама тощо. Також держава опікується питанням підготовки фахівців для роботи в туристичній галузі.

Управління туристичною галуззю здійснюється, зазвичай, через спеціальний адміністративний орган, зокрема, Національну туристичну адміністрацію або департаменти туризму при уряді тощо. Їхня роль у різних державах неоднакова

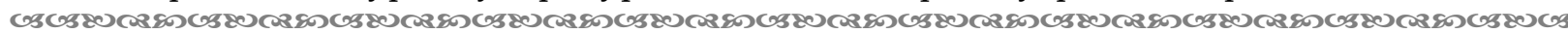
203 
і значною мірою залежить від позиції цього спеціалізованого органу в структурі державної влади й ступеня втручання держави в просування туристичного продукту.

У науковій літературі визначено моделі управління туристичною діяльністю. Зокрема, модель перша передбачає усі питання розв'язувати через ринкові механізми. Для цього необхідні міцні позиції на міжнародному ринку туризму, привабливість країни для туристів і наявність потужних приватних туристичних компаній [6].

У другій моделі передбачається наявність міністерства, яке повністю контродює туристичну діяльність. При цьому забезпечуються значні фінансові вкладення в індустрію туризму. Управління туристичною діяльністю за цією моделдю поширене в Туреччині, Єгипті, Тунісі та інших країнах, де туризм є одним із основних джерел валютних надходжень.

Модель третя характерна для країн, де проблемами туризму займається певне міністерство, в якому є підрозділ державного управління туристичною галуззю. Дана модель впроваджена, зокрема, і в Україні.

У Законі України «Про туризм»є розділ II, який називається «Державна політика та державне регулювання в галузі туризму». В ньому, зокрема, сказано, що держава проголошуе туризм одним із пріоритетних напрямів розвитку економіки та кудьтури і створюе умови для туристичної діяльності [1].

Основні напрями державного управління в галузі туризму визначено такі: забезпечення прав громадян на відпочинок, відновлення і зміцнення здоров'я; безпека туризму; раціональне використання туристичних ресурсів України; створення сприятливих умов для розвитку індустрії туризму; підтримка пріоритетних напрямів туристичної діяльності.

В Україні використовуються певні засоби регулювання туристичної діяльності, за допомогою яких забезпечується державний контроль. Засобами контролю є стандартизація, сертифікація та ліцензування в галузі туризму.

Стандартизація - це діяльність, що забезпечує відповідність продукції їхньому функціональному призначенню. Завдяки стандартизації споживачі інформовані про якість продукції, розвиток їі міжнародної конкурентоспроможності, сприяе усуненню бар'єрів у торгівлі тощо.

Стандартизація використовується на різних рівнях. На міжнародному рівні участь у ній відкрита для відповідних органів усіх країн. На регіональному рівні стандартизація забезпечує участь відповідних органів країн певного географічного або економічного простору. Національна стандартизація проводиться на рівні однієї країни [5].

Українська система стандартизації у сфері туристичної діяльності спрямована на підвищення якості товарів, робіт, послуг відповідно до потреб споживачів, а також на захист інтересів споживачів і держави з питань безпеки туризму, життя і здоров'я громадян, охорони майна та довкілля.

В Україні проведено стандартизацію різних видів туристичної діяльності, професійних назв робіт, засобів розміщення, закладів ресторанного господарства, а також продукції, яка виробляеться в туризмі.

Результатами стандартизації е відповідні класифікації - документи, у яких згруповано та систематизовано інформацію про явища в стандартний формат, узгоджений 3 міжнародними статистичними класифікаціями, де кожному явищу надано певний код, що позначає об'єкт класифікації.

Стандартизація продукції, яка виробляється в туризмі, відображена в статистичній класифікації продукції за видами економічної діяльності. Зазначимо, що під продукцією розуміють резудьтат виробничого процесу, який містить як товари, так і послуги. Відповідно до СКП, затвердженої розпорядженням Кабінету Міністрів України, можна виділити такі структурні ієрархії продукції туристичного призначення: послуги готелів та ресторанів; послуги у сфері державного управління; послуги громадських організацій; послуги у сфері культури та спорту, відпочинку та ін.

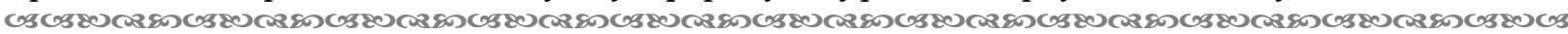
204 
Будь-який суб'єкт ринку туристичних послуг, що виробляе продукцію, зобов'язаний дотримуватися встановлених стандартів, що підтверджують iii відповідність 3 метою підвищення рівня туристичного обслуговування.

За умови успішної сертифікації заявнику видається спеціальний юридичний документ - сертифікат відповідності. Він засвідчуе, що певні послуги і товари, об'єкт, персонал тощо відповідають установленим вимогам конкретного стандарту чи іншого нормативного документа, визначеного чинним законодавством, що перевіряеться органом сертифікації [4].

Дієвим шляхом регулювання діяльності у сфері туризму є діцензування. Йдеться про процедуру одержання певного дозволу, що надається як документ - діцензія. Діцензування - це створення однакових мождивостей для всіх суб'єктів туристичної діяльності на ринку туристичних послуг i, водночас, забезпечення захисту їхніх прав і законних інтересів. Це стосується як тих, хто надає такі послуги (туристичних компаній), так і споживачів цих послуг (туристів). Діцензування здійснюеться також із метою забезпечення підвищення рівня туристичного обслуговування та захисту навкодишнього природного середовища.

В Україні з дистопада 2010 р. ліцензуванню підлягає туроператорська діяльність. 32011 р. органом діцензування визначене Державне агентство України 3 туризму та курортів. Суб'єкт підприємницької діяльності, який отримав ліцензію на туроператорську діяльність (діцензіат), має виняткове право на надання послуг 3 оформлення документів для виїзду за межі України.

Провадження туроператорської діяльності в Україні передбачає дотримання низки діцензійних вимог. Зокрема, це надання туристичних послуг в обсягах та в строки, обумовлені умовами договору про туристичне обслуговування. Також необхідно виконувати вимоги законодавства України в сфері міграції, недопущення фактів здійснення незаконної угоди, об'єктом якої є людина, а також інформувати туристів про можливі небезпеки під час подорожі, необхідність виконання загальнообов' язкових вимог, попереджувальних заходів тощо.

У туроператора повинні зберігатися:

- діцензія на провадження туроператорської діяльності;

- документи, що підтверджують фінансове забезпечення цивільної відповідальності перед туристами;

- угоди із страховиками (медичне страхування та від нещасного випадку), які повинні передбачати надання медичної допомоги туристам та відшкодування їхніх витрат при настанні страхового випадку безпосередньо в країні тимчасового перебування;

- договори на туристичне обслуговування з туристами [5].

Туроператор повинен відшкодовувати матеріальні і моральні збитки у разі невиконання або неналежного виконання умов договору на туристичне обслуговування; укладати з туристом договір про туристичне обслуговування в письмовій формі. При укладанні договору на туристичне обслуговування турист проставляе свій підпис у паперовій формі цього договору, чим підтверджує, що він ознайомився 3 його умовами до укдадання цього договору.

Ліцензійні вимоги до забезпечення страхового захисту туристів спрямовані на доведення до відома туриста інформації та обов'язкове страхування. На вимогу туриста туроператор забезпечує страхування інших ризиків, пов'язаних зі здійсненням подорожі.

Туроператор під час організації виїзного туризму повинен оформити та видати туристу договір на туристичне обслуговування або ваучер, договір на обов'язкове медичне страхування. Діцензування дає змогу досить оперативно відстежувати і контродювати ситуацію щодо основних суб'єктів на національному туристичному ринку.

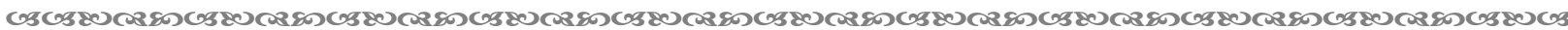
205 
Одним із способів державного управління туристичною діяльностю є стандартизація. Стандартизація - це діяльність 3 установлення норм, правил і характеристик із метою забезпечення безпеки продукції, робіт, послуг для навкодишнього середовища, життя, здоров'я та майна громадян, якості продукції, відповідно до рівня розвитку науки, техніки і технодогії.

Метою стандартизації у сфері туризму є нормативне забезпечення підвищення якості та ефективності туристичного та екскурсійного обслуговування і захист інтересів споживачів туристичних послуг [6].

Основні завдання стандартизації у сфері туризму полягають у встановленні: термінів і визначень основних понять у галузі стандартизації та управління якістю туристично-екскурсійного обслуговування; прогресивних вимог до технологї̈ й типових технологічних процесів надання туристичних послуг; вимог до сертифікації туристичних послуг.

Крім того, стандартизація спрямована на забезпечення: координації діяльності туристичних агенцій з підприємствами інших галузей, які беруть участь у процесах туристично-екскурсійного обслуговування, безпеки туристичних об'єктів, раціонального використання туристичних ресурсів.

Стандарт - це нормативний документ, розроблений за згодою більшості зацікавлених сторін, у якому встановлюються для загального застосування типові правила, характеристики, методи, що стосуються різних видів діяльності та спрямовані на досягнення оптимадьного ступеня їхньої відповідності науково-технічним досягненням та упорядкування у певній галузі.

В Україні розроблено низку національних стандартів у галузі туризму. Терміни, встановлені стандартом, обов' язкові для вживання в усіх видах нормативних документів, що стосуються сертифікації послуг із тимчасового розміщування, для визначення категорій готелів та інших об'єктів, що надають послуги з тимчасового проживання, а також для робіт зі стандартизації [5].

Крім зазначених національних, в Україні діють міжнародні стандарти в галузі туризму в межах різних держав і відповідно до «Положення про Міждержавну раду по стандартизації, метрології і сертифікації».

Висновки. Незважаючи на складні політичні, соціально-економічні умови, карантинні обмеження останніх років вітчизняний туризм розвивається як пріоритетна галузь господарського комплексу країни, без залучення державних дотацій нарощує обсяги продукування та реалізації туристичних продуктів і є джерелом бюджетних надходжень, засобом повноцінного відпочинку й оздоровлення, а також ознайомлення з історико-кудьтурною спадщиною України та світу. Управління туристичною діяльністю в Україні здійснюється на державному та регіональному рівнях та пов'язано з відповідними економічними та історичними умовами розвитку країни. На основі функцій координування, планування, регулювання, маркетингу формується туристична подітика держави.

Перспективи подальших розвідок щодо управління туристичною діядьністю в Україні ми вбачаємо в розробці технології реалізації туристичного продукту, практичних рекомендацій щодо організування туристичної діяльності, проєктування системи підготовки фахівців для туристичної індустрії тощо.

\section{Список використаних джерел:}

1. Про туризм. Закон України. URL: https://zakon.rada.gov.ua/laws/main/324/95-вp\#Text (дата звернення: 16.10.2020).

2. Кифяк В. Ф. Організація туризму: навч. посіб. Чернівці: Книги XXI. 2008. 344 с.

3. Кіптенко В. К. Менеджмент туризму: підручник. Київ: Знання. 2010. 502 с.

4. Кудла Н. Є. Управління якістю в туризмі: підручник. Київ: Центр учбової літератури. 2014. 328 c. 
5. Кузьмін О. Є., Дубодєлова А. В., Кудинюк І. Я., Маклуш Х. Ю. Організування туристичної діяльності: навч. посіб. Аьвів: Видавництво Аьвівської політехніки, 2015. 352 с.

6. Пестушко В. Ю. Туризм. Вступ до фаху: навч. посіб. Київ: НАУ, 2015. 276 с.

\section{References:}

1. Law of Ukraine About tourism (2020, 16 October). Retrieved from https://zakon.rada.gov.ua/laws/main/324/95-вр\#Text [in Ukrainian].

2. Kyfiak, V.F. (2008). Orhanizatsiia turyzmu [Organization of tourism]. Chernivtsi: Knyhy XXI [in Ukrainian].

3. Kiptenko, V. K. (2010). Menedzhment turyzmu [Tourism management]. Kyiv: Znannia [in Ukrainian].

4. Kudla, N. Ye. (2014). Upravlinnia yakistiu v turyzmi [Quality management in tourism]. Kyiv: Tsentr uchbovoi literatury [in Ukrainian].

5. Kuzmin, O. Ye., Dubodielova, A. V., Kulyniuk, I. Ya., \& Maklush, H. Yu. (2015). Orhanizuvannia turystychnoi diialnosti [Organization of tourist activities]. Lviv: Vydavnytstvo Lvivskoi politekhniky [in Ukrainian].

6. Pestushko, V. Yu. (2015). Turyzm. Vstup do fakhu [Tourism. Entry to the profession]. Kyiv: NAU [in Ukrainian].

\section{MANAGEMENT OF THE TOURIST ACTIVITY IN UKRAINE: THEORETICAL ASPECT}

Shorobura I. M., orcid.org/0000-0003-3728-7968

The article reveals the theoretical aspects of management of the tourist activity in Ukraine. The attention is paid to regulation, coordination, stimulation, information support, promotion of the national tourist product advancement. The models of management of the tourist activity have been covered. In particular, the first model focuses on solving touristic problems through market mechanisms. The second model provides for the existence of the ministry that controls tourist activity; in the third - at the ministry there is a division which is engaged in tourist activity. Emphasis is placed on the main means of regulating tourist activity, such as: standardization, certification and licensing in the tourism sector. Certification is an activity that ensures the conformity of products to the functional purpose. It is a set of actions and procedures performed to confirm that the product or service meets certain standards, it is a documentary evidence of compliance of the product or other objects, production processes, operation of services with the provisions of standards or contract terms. Licensing is defined as the granting of a specific permit for tourist activity. This is the process of issuing, reissuing and revoking licenses, maintaining license files and registers, monitoring compliance with license conditions, issuing orders to eliminate violations of license conditions. Standardization is revealed as the establishment of norms and rules to ensure the safety of tourist services. It is stated that the purpose of standardization in the field of tourism is to ensure the quality and efficiency of tourist excursion services and protect the interests of consumers of tourist services.

Despite the difficult political, socio-economic conditions, quarantine restrictions in recent years, domestic tourism is developing as a priority sector of the economic complex of Ukraine.

Key words: tourist activity, Ukraine, management, models of tourist activity management, means of tourist activity management. 